\title{
No room for experiment: the Federal Circuit's narrow construction of the experimental use defense
}

\author{
A recent decision in Madey v. Duke University turns the experimental use defense into a practical \\ nullity for research institutions.
}

\author{
S. Peter Ludwig and Jason C. Chumney
}

Erese or many years, American educational and research institutions have deflected suggestions that their research activities run afoul of in-force patents by pointing to the so-called experimental use doctrine. The doctrine, established by court decisions in the 1800 s, once held that activities undertaken "without any intent to derive profits or practical advantage" did not constitute patent infringement ${ }^{1}$. Relying upon the doctrine, educational institutions felt sufficiently secure to undertake activities under the rubric of 'research' that would otherwise fall squarely into the realm of actionable patent infringement.

While legitimate 'blue sky' academic research was never a serious target for patent owners, the issue became murkier with the advent of big dollar, corporate-sponsored research projects. Nowadays, it is not unusual for university personnel to receive millions of dollars in sponsored research funding from both public and private companies. These 'sponsored research' projects are often carried out in university laboratories by university personnel, using dollars and sometimes 'know-how' from corporate sponsors.

A recent decision makes clear that nonprofit research institutions will now be afforded little, if any, protection under the third-party experimental use defense to patent infringement. In Madey v. Duke University, a three-judge panel of the US Court of Appeals for the Federal Circuit (CAFC; the premiere adjudicator of US patent law) ruled that the defense "does not immunize any conduct that is in keeping with the alleged infringer's legitimate business, regardless of commercial implications." ${ }^{2}$ The decision-one of a limited number involving research institutions-continues a trend towards a strict interpretation of what the CAFC now describes as "the very narrow and strictly limited experimental use defense."

In Madey, the plaintiff was a former research professor at Duke University, and

S. Peter Ludwig is a firm member and Jason Chumney is an associate at Darby \& Darby P.C., 805 Third Avenue, New York, NY 10022 (pludwig@darbylaw.com). owner of two patents covering equipment in a laboratory which he oversaw. After a nonamicable parting, the Duke lab continued to operate the equipment in furtherance of an Office of Naval Research (ONR) grant. Madey subsequently brought suit against Duke for patent infringement based on Duke's continued use of his patented equipment in the lab.

At trial, Duke successfully defended, based on, among other things, the experimental use defense. On appeal, the CAFC stated that activity "does not qualify for the experimental use defense when it is undertaken in the guise of scientific inquiry but has definite, cognizable, and not insubstantial commercial purposes." Going further, the court noted that research projects at "major research universities" often have "no commercial application whatsoever" but may nonetheless further the institution's "legitimate business objectives, including educating and enlightening students and faculty participating in these projects." When such research furthers "the institution's legitimate business objectives," infringement is possible, "regardless of commercial implications."

Once thought to broadly shield research endeavors from patent infringement scrutiny, the experimental use defense traces its roots to 1813 case law. Justice Story, sitting on the Massachusetts Circuit Court, remarked that "it could never have been the intention of the legislature to punish a man, who constructed ... a [patented] machine merely for philosophical experiments. ..." ${ }^{4}$ By 1861, it was deemed by one court to be "well settled" that experimentation "for the sole purpose of gratifying a philosophical taste, or curiosity, or for mere amusement" is not patent infringement ${ }^{5}$. In 1935, a trial court invoked the doctrine to shelter activities undertaken "without any intent to derive profits or practical advantage ...."

The CAFC has retreated from these relatively broad 'safe-harbors' set forth by earlier courts. In Roche Products, Inc. v. Bolar Pharmaceutical Co., it was held that the experimental use doctrine did not protect the "limited use of a patented drug for testing and investigation strictly related to US Food and Drug Administration (FDA) drug approval requirements." ${ }^{6}$ Congress, partially in response to Roche Products, enacted 35 USC $\$ 271(\mathrm{e})$, which specifically exempts uses "reasonably related to the development and submission of information" to the FDA. It was an open question whether the CAFC's narrow reading of the experimental use doctrine in Roche survived $\$ 271(\mathrm{e}){ }^{7}$

In two subsequent decisions-Embrex, Inc. v. Service Engineering Corp. ${ }^{8}$ and particularly Madey v. Duke University- the CAFC reaffirmed its adherence to the narrow position set forth in Roche Products. After Madey, it is questionable whether the experimental use doctrine continues to provide a viable defense against patent infringement liability.

Considering the aims of nonprofit research institutions, most activities would appear to further the legitimate business objectives of enlightening students and faculty. Otherwise, why undertake the research? Under the CAFC's view, nonprofits should be aware that courts will not provide relief from the patent laws, constitutionally mandated, ironically, to "promote the progress of [s] cience and useful [a]rts." ${ }^{\prime}$ Although nonprofits have attempted to obtain relief through Congress ${ }^{10}$, like that successfully obtained by the generic drug industry, such efforts have to date proven fruitless. Thus for now, nonprofits must not only consult their scientists in determining whether something is possible, but also their lawyers.

1. Ruth v. Stearns-Roger Mfg. Co., 13 F. Supp. 697, 713 (D. Colo. 1935)

2. Madey v. Duke Univ., No. 01-1567, 2002 WL 31190842 (Fed. Cir. October 3, 2002)

3. Id.

4. Whittemore v. Cutter, 29 F. Cas. 1120, 1121 (No. 17,600) (C.C.D. Mass. 1813)

5. Poppenhusen v. Falke, 19 F. Cas. 1048, 1049 (No. 11,279) (C.C.S.D. N.Y. 1861).

6. Roche Products, Inc. v. Bolar Pharmaceutical Co., 733 F.2d 858, 861 (Fed. Cir. 1984).

7. Chisum, D.S. Chism on Patents. 5, §16.03[1][c] (Matthew Bender, Release No. 84, August 2002)

8. 216 F.3d 1343 (Fed. Cir. 2000).

9. US Constitution, Art. I, §8, cl. 8 .

10. Barash, E.H. Experimental uses, patents, and scientific progress. Northwestern U. L. Rev. 91, 667, 695 (1997) (discusses the Proposed Competitiveness and Technological Innovation Act of 1990, which included provisions calling for a significant expansion of the breadth of non-infringing experimental use). 